Reviews

\title{
The Use of Noble Gas Isotopes in Detecting Methane Contamination of Groundwater in Shale Gas Development Areas: An Overview of Technology and Methods
}

\author{
Chunhui CaO, ${ }^{*, * * \dagger}$ Liwu LI,,$* *$ Li Du,,$* * *$ Yuhui WANG, ${ }^{*}, * *, * * *$ and Jian HE$*, * * *$ \\ *Northwest Institute of Eco-Environment and Resources, Chinese Academy of Sciences, Lanzhou 730000, China \\ **Key Lab of Petroleum Resources, Gansu Province/Key Lab of Petroleum Resources Research, Institute of \\ Geology and Geophysics, CAS, Lanzhou 730000, China \\ ***College of Earth Science, University of the Chinese Academy of Sciences, Beijing 100049, China
}

\begin{abstract}
Groundwater contamination by stray gas (mainly methane) in areas of shale-gas development has captured publics, political and scientific attention. However, the sources and potential mechanisms of groundwater contamination are still debated. Noble gases can provide useful information on fluid migration for discerning the scale, conditions, and physical mechanisms. In this study, details about analytical technology and theoretical approach of noble gases in tracing groundwater contaminations are presented. In addition, applications of noble-gases isotopes for determining contamination sources and potential pathways are explored and reviewed. Recent developments are discussed and highlighted with focusing on new utilities of noble-gas isotope parameters in evaluating groundwater contamination. Some usages of indicators $\left({ }^{4} \mathrm{He} /{ }^{20} \mathrm{Ne}, \mathrm{CH}_{4} /{ }^{36} \mathrm{Ar},{ }^{4} \mathrm{He} / \mathrm{CH}_{4}\right.$, etc. $)$ are discussed through specific research articles. And it is a new trend to make comprehensive use of multiple geochemical parameters to determine the occurrence, source, and process of methane pollution in groundwater.
\end{abstract}

Keywords Groundwater contamination, isotope tracing, stray gas, noble gas, shale gas development area

(Received December 31, 2019; Accepted March 5, 2020; Advance Publication Released Online by J-STAGE March 13, 2020)

1 Introduction

2 Empirical and Theoretical Approach

3 Noble Gas Isotope Instrumentation

4 Sample Preparation and Analysis Procedures

$4 \cdot 1$ Groundwater samples collection

4.2 Gas extraction and purify

4.3 Noble gas measurement procedures

5 Applications of Noble Gases in Groundwater Contamination
521

523

524

525

6 Conclusions and Perspectives

7 Acknowledgements

8 References

\section{8}

528

528

526

\section{Introduction}

Shale gas has become an increasingly important source of natural gas in the United States and many other countries, due to

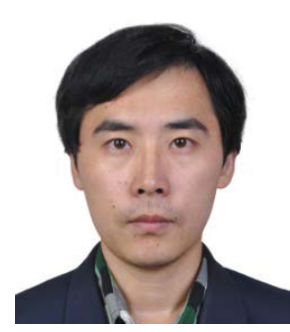

Chunhui CaO received his Ph.D. degree in 2017. He is an engineer at Northwest Institute of Eco-Environment and Resources (NIEER), Chinese Academy of Sciences. He is in charge in a noble gas isotope laboratory in NIEER. He is engaged in analytical techniques of noble gas and stable isotope compositions, and has long been engaged in stable and rare gas isotope geochemistry and oil and gas geochemistry research. the development of hydraulic fracturing and horizontal drilling technology. ${ }^{1-3} \quad$ Nevertheless, both horizontal drilling and hydraulic fracturing operations require a significant amount of freshwater, which results in water consumption as well as drinking water contamination. ${ }^{4-8}$ Evidence has been found in

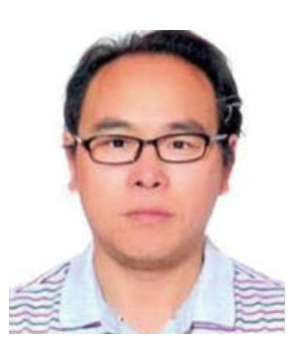

Liwu LI received a Ph.D. He is a researcher at Northwest Institute of Eco-Environment and Resources, Chinese Academy of Sciences. He is good at instrument analysis, and is proficient in large-scale analytical instruments such as rare gas isotope mass spectrometers, stable isotope mass spectrometers, and gas chromatographs.

$\dagger$ To whom correspondence should be addressed.

E-mail: storm1983hui@163.com 


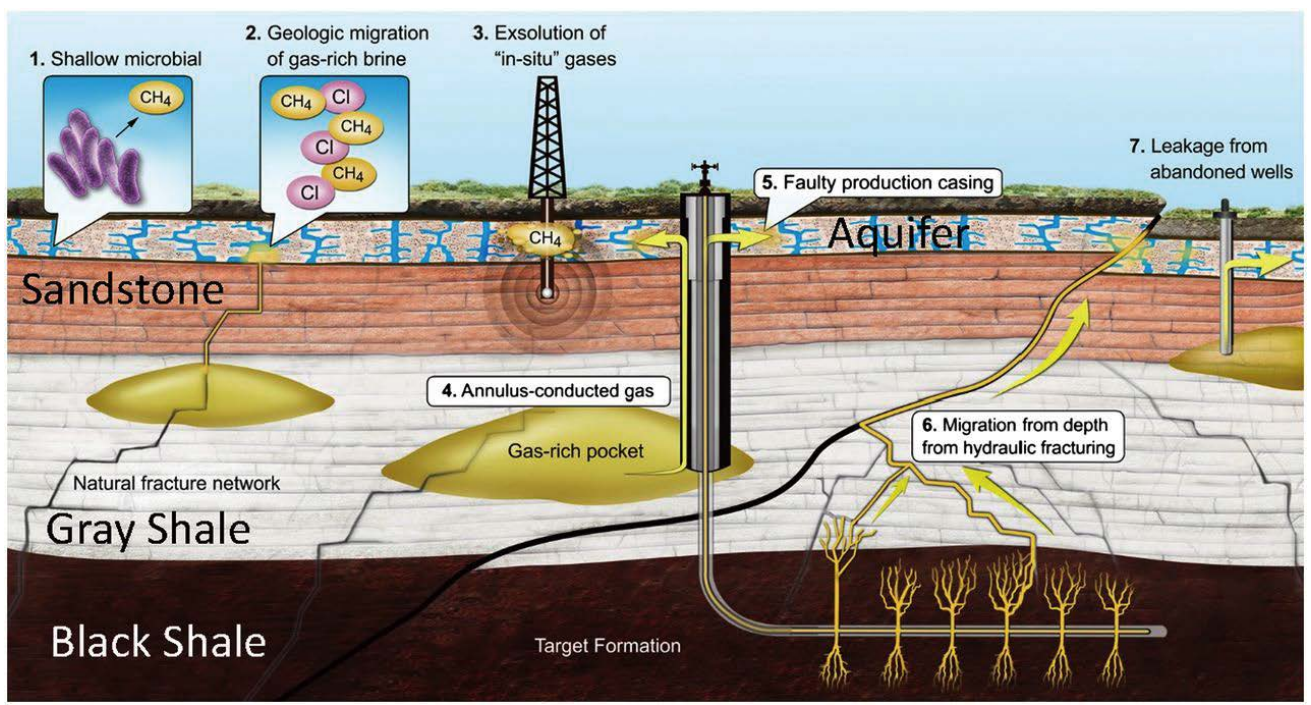

Fig. 1 Seven possible scenarios that may account for the presence of elevated hydrocarbon gas levels in shallow aquifers. Reprinted from Ref. 34, Copyright (2014), with permission from the NAS.
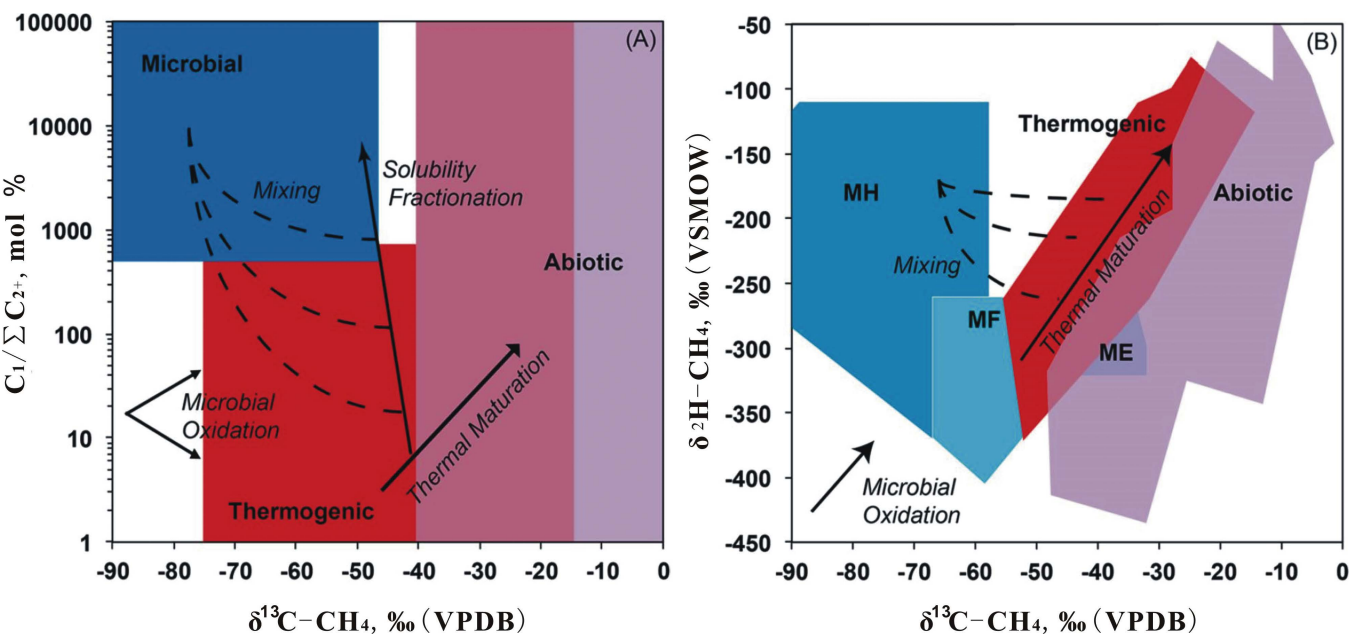

Fig. 2 Hydrocarbon gas isotope fingerprinting approaches for identifying the sources of natural gas. MH, Hydrogenotrophic methanogenesis; MF, acetate fermentation; ME, methanogenesis in evaporitic environments. Reprinted from Ref. 52, Copyright (2019), with permission from the ACS.

many countries that the development of shale-gas resources by hydraulic fracturing possibly leads to fugitive gas contamination of the overlying aquifers., ${ }^{7-17}$ Thus, despite the economic benefits of shale-gas extraction, ${ }^{18-20}$ public concerns about environmental issues are growing. ${ }^{14,21-27}$

Shale-gas development may contaminate the ground and surface water by a number of mechanisms (Fig. 1) and thereby impact the public or private drinking water. ${ }^{12,27-30}$ Stray gas, which refers to natural gas present in shallow aquifers of undetermined origin, ${ }^{31}$ may come from shallow or deep thermogenic gas accumulations of natural or anthropogenic origin (caused by shale-gas development activities), ${ }^{12,32-36}$ from shallow microbial sources or a combination of both. ${ }^{11,31,37-39,40}$ On one hand, horizontal drilling and hydraulic fracturing technology require the injection fracturing fluid, which contains up to 1084 chemicals, ${ }^{28,41}$ into the shale during the extraction process. If the fracturing fluid penetrates underground or overflows during rainy seasons, it can easily pollute local shallow and underground water. ${ }^{7,12,42}$ On the other hand, shale gas may leak out of gas wells into shallow aquifers and dissolve.

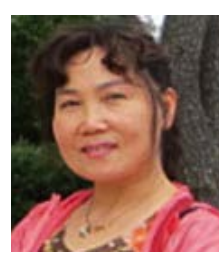

Li DU is an assistant researcher at Northwest Institute of EcoEnvironment and Resources, Chinese Academy of Sciences She is engaged in analytical techniques of Gas molecular composition.

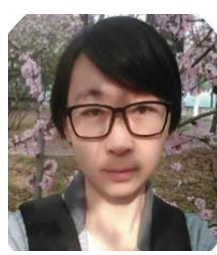

Yuhui WANG is a PhD studen of College of Earth Science, University of the Chinese Academy of Sciences. She is engaged in analytica techniques of noble gas isotope compositions.

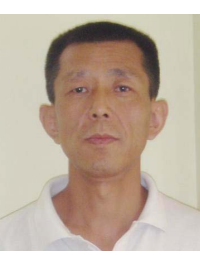

Jian HE is an assistant researcher at Northwest Institute of Eco-Environment and Resources, Chinese Academy of Sciences. He has been engaged in the analysis and testing of noble gas isotopes. 
Table 1 Average concentrations and isotopic ratios of the principal reservoirs of noble-gas compounds ${ }^{69}$

\begin{tabular}{lcccccccccc}
\hline & ${ }^{4} \mathrm{He}$ & ${ }^{20} \mathrm{Ne}$ & ${ }^{36} \mathrm{Ar}$ & ${ }^{84} \mathrm{Kr}$ & ${ }^{132} \mathrm{Xe}$ & $R / R_{\mathrm{a}}$ & ${ }^{20} \mathrm{Ne} / 22 \mathrm{Ne}$ & ${ }^{21} \mathrm{Ne} /{ }^{22} \mathrm{Ne}$ & ${ }^{40} \mathrm{Ar} /{ }^{36} \mathrm{Ar}$ \\
\hline Atmosphere, ppm & 5.24 & 16.5 & 31.4 & 0.65 & 0.023 & 1 & 9.8 & 0.029 \\
ASW $^{\mathrm{a}}\left(20^{\circ} \mathrm{C}\right.$, fresh water $) / \mu \mathrm{mol} \mathrm{m}{ }^{-3}$ & 2.04 & 7.67 & 47.8 & 1.83 & 0.039 & 1 & 9.8 \\
MORB $^{\mathrm{b}}$ mantle & 36600 & 1.04 & 1 & 0.029 & 0.004 & 8 & $12.5-13.8$ & $0.06-0.063$ & 40000 \\
Continental crust & - & - & - & - & - & 0.02 & $0.08-0.10$ & $0.4-0.52$ & 3000 \\
\hline
\end{tabular}

a. ASW: Atmospheric saturated water. b. MORB: Mid-ocean ridge basalt.

This migration may be caused by natural fracture systems as well as the failing or improperly installed casings in the natural gas wells. ${ }^{7,43,44}$ Although groundwater contamination caused by drilling and hydraulic fracturing is ubiquitous, its sources need to be determined and the impact of these potential pathways (e.g., horizontal drilling, hydraulic fracturing, and wellbore) on water quality remains controversial. ${ }^{12,45-48}$

Many researchers have studied groundwater contamination by using molecular and stable-carbon-isotope compositions of hydrocarbons. ${ }^{12,14,33,49-52}$ These tracers are traditionally used to identify the sources of hydrocarbon dissolved in groundwater, and distinguish biogenic or thermogenic sources (Fig. 2). However, new methods were needed to distinguish natural processes from fugitive gas contamination. ${ }^{44}$ Noble gases can provide fluid migration information to complement hydrocarbon geochemistry, ${ }^{44,53}$ because they are chemically inert and have distinct isotopic composition in the atmosphere, crust, and mantle..$^{34,54-57}$ In addition, noble gases can exactly quantify hydrocarbon migration because each inert tracer $(\mathrm{He}, \mathrm{Ne}, \mathrm{Ar}$, $\mathrm{Kr}$, and $\mathrm{Xe}$ ) has unique solubility and diffusion constants when fractionated during fluid migration. ${ }^{44,54,56-59}$ So, many researchers have begun to exploit noble gases to investigate the sources and potential pathways of groundwater contamination. ${ }^{31,34-36,60-65}$

\section{Empirical and Theoretical Approach}

Three unique geochemical characteristics of stable noble gases enhance their utility as geochemical tracers of crustal fluids. ${ }^{56}$ First, unlike the hydrocarbon composition, stable noble gases $(\mathrm{He}, \mathrm{Ne}, \mathrm{Ar}, \mathrm{Kr}, \mathrm{Xe})$ are a set of non-reactive geochemical tracers. The inert nature of noble gases enables the original composition is independent of the microbial activity, chemical reactions (e.g., sulfate reduction), or changes in the oxygen fugacity. ${ }^{54,55,67}$ Second, the concentrations of noble gases in subsurface fluids (e.g., freshwater, natural gas) are extremely low, and strongly fractionated noble gas ratios can be transferred between the gas or water phase; consequently, they can reflect extraordinary tiny changes in the groundwater. ${ }^{57}$ Third, noble gases in geological fluids are primarily derived from three sources: the atmosphere, crust, and mantle, all of which show distinct isotopic and elemental signatures. ${ }^{54,68}$ The distinction in abundance and isotope ratios of noble gases can not only discern the sources (Table 1) ${ }^{69}$ of groundwater contamination, but also identify the specific migration (Fig. 3). ${ }^{34,53,62}$

In addition, noble gases have different solubility and diffusion constants in different fluid phases (e.g., oil, natural gas, and groundwater, Table 2). ${ }^{44,57-60}$ The relative fractionation of noble gases during migration of these fluids could provide more information for indicating their potential migration pathways (Fig. 4) ${ }^{57}$ The mechanism of gas transport to shallow aquifers is the key to distinguish between natural and anthropogenic sources of hydrocarbons in groundwater. In crustal fluids, noble gases fractionate only by well-constrained physical mechanisms (e.g., diffusion, phase partitioning).$^{54}$ The specific diffusion and solubility constants of each noble gas can quantify hydrocarbon migration, and when paired with the hydrocarbon composition and inorganic water chemistry, noble gases can help differentiate between natural geological migration of hydrocarbon gases and anthropogenic contamination. . $^{34,44}$

The atmospheric noble gas isotopes $\left(\right.$ e.g., ${ }^{20} \mathrm{Ne},{ }^{36} \mathrm{Ar},{ }^{84} \mathrm{Kr}$, ${ }^{130} \mathrm{Xe}$ ), which are derived from solubility equilibrium with the atmosphere during groundwater recharge, are essential potential tracers for fugitive gas contamination because they have a consistent source globally and are sensitive tracers to water-gas interactions. ${ }^{34,44,70,71}$ The phenomenon of "stripping" will occur when crustal gases migrate through groundwater, which means the atmospheric noble gases that originally dissolved in groundwater, will partition into the bubble phase and migrate quickly; ${ }^{44,71,72}$ meanwhile, these atmospheric gases would redistribute according to their respective solubility. ${ }^{56}$ If subsurface fluids migrated by two-phase advection (i.e., brine + free gas), both helium and neon would be gathered in the migrated gas phase; yet, in the free gas, the concentrations of light noble-gas isotopes decrease as the gas/water ratio increases. However, in single-phase fluids, noble gases would not experience any quantifiable fractionation, but would also result in an increase in the ${ }^{4} \mathrm{He} / \mathrm{CH}_{4}$, because of radiogenic ${ }^{4} \mathrm{He}$ coming from surrounding rocks. ${ }^{35}$ Thus, when similar gas fractionation processes occurs in gas-rich samples $>1 \mathrm{~km}$ from the drilling are spot, we could confirm the hydrocarbon gases are able to migrate significant distances from the target shale formations to shallow aquifers following hydraulic stimulation. Otherwise, it appears that hydrocarbon gases have not interacted with the water-saturated crust fluid, so, the most likely pathway by which they migrated thousands of feet into shallow aquifers is either (a) along the well annulus, (b) through faulty or corroded casing, or (c) along legacy or abandoned wells (Fig. 1). ${ }^{44}$

In previous studies, the isotopic composition $\left(e . g .,{ }^{20} \mathrm{Ne} / 22 \mathrm{Ne}\right.$, ${ }^{21} \mathrm{Ne} /{ }^{22} \mathrm{Ne}$, or ${ }^{40} \mathrm{Ar} /{ }^{36} \mathrm{Ar}$ ) and relative abundance of ASW (i.e., ${ }^{20} \mathrm{Ne} /{ }^{36} \mathrm{Ar}$ ) and crustal (i.e., ${ }^{4} \mathrm{He},{ }^{4} \mathrm{He} / \mathrm{CH}_{4},{ }^{4} \mathrm{He} /{ }^{20} \mathrm{Ne}$, or ${ }^{4} \mathrm{He} /{ }^{36} \mathrm{Ar}$ ) gas components are often used to identify the source, mixtures, history of migration, and interactions that occur between fluids (e.g., gas and water) in the Earth's crust (Figs. 3 and 4). ${ }^{31,34,36,44,61,73}$ Methane, ethane, and radiogenic ${ }^{4} \mathrm{He}$ (produced by the decay of $\mathrm{U}$ and $\mathrm{Th}$ ) dominate thermogenic natural gases, while ${ }^{20} \mathrm{Ne}$ and ${ }^{36} \mathrm{Ar}$ are sourced predominantly from the atmosphere, so, the $\mathrm{CH}_{4} /{ }^{36} \mathrm{Ar}$ and ${ }^{4} \mathrm{He} /{ }^{20} \mathrm{Ne}$ ratios allow a direct comparison of the proportion of thermogenic natural gases and ASW components.

On the whole, these facts make noble gases ideal natural tracers for studying the sources, potential transport mechanisms, and potential pathways on groundwater contamination. ${ }^{31,34-36,59,61-66,70}$ And recent studies make good use of noble gases in studying groundwater quality problems in natural gas development areas. . $^{31,34,36,44,59,61,62,65,66,73}$ 

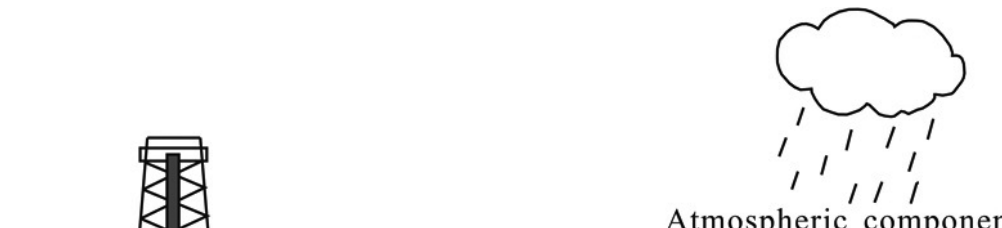

Atmospheric component ${ }^{3} \mathrm{He} /{ }^{4} \mathrm{He}=1.4 \times 10^{-6}$ ${ }^{20} \mathrm{Ne} /{ }^{22} \mathrm{Ne}=9.80$ ${ }^{=1} \mathrm{Ne} /{ }^{22} \mathrm{Ne}=0.029$
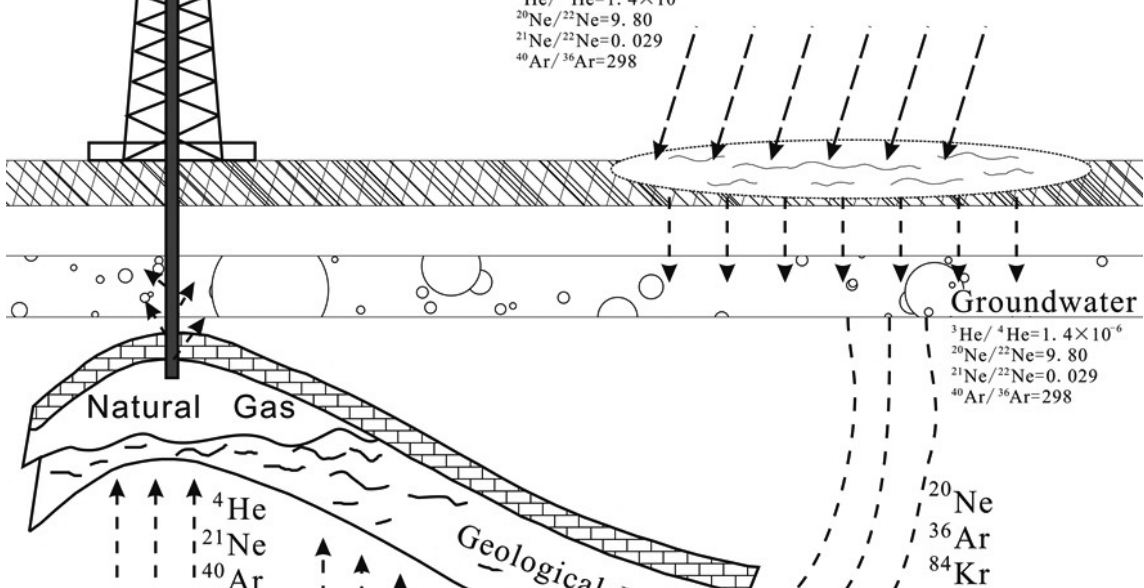

Crust radiogenic component ${ }^{3} \mathrm{He} /{ }^{4} \mathrm{He}=1.4 \times 10^{-8}$ ${ }^{4} \mathrm{He}_{\text {rad }} /{ }^{40} \mathrm{Ar}_{\text {rad }}=4.9$ ${ }^{4} \mathrm{He}_{\text {rad }} /{ }^{21} \mathrm{Ne}_{\mathrm{rad}}=9 \times 10$

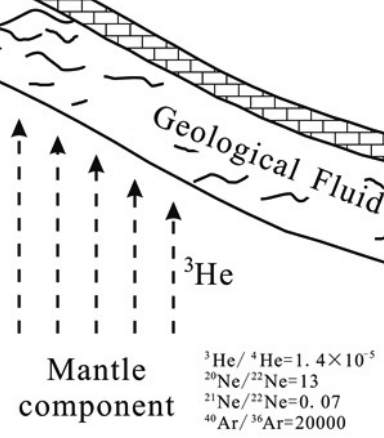

${ }^{40} \mathrm{Ar} /{ }^{36} \mathrm{Ar}=298$

$\begin{array}{lll}1 & 1 & 1\end{array}$

$1 \quad 11$

$1,1^{20} \mathrm{Ne}$

, $136 \mathrm{Ar}$

$, \quad, \quad{ }^{84} \mathrm{Kr}$

1 I

${ }^{20} \mathrm{Ne} / 2{ }^{22} \mathrm{Ne}=13$

${ }^{40} \mathrm{Ar} /{ }^{36} \mathrm{Ar}=20000$

Fig. 3 Schematic diagram illustrating noble-gas components in various reservoirs and their immigration. Reprinted from Ref. 69, Copyright (2013), with permission from Springer Nature.

Table 2 Parameter used in single-stage and two-stage fractionation models

\begin{tabular}{|c|c|c|c|c|c|c|}
\hline \multirow{2}{*}{$\begin{array}{c}\text { Temperature/ } \\
{ }^{\circ} \mathrm{C}\end{array}$} & \multirow{2}{*}{$\begin{array}{c}\text { Salinity/ } \\
\text { M }\end{array}$} & \multicolumn{5}{|c|}{ Henry's Constants for Water Phase/atm } \\
\hline & & $\mathrm{He}$ & $\mathrm{Ne}$ & Ar & $\mathrm{Kr}$ & $\mathrm{Xe}$ \\
\hline 18 & 0 & 141 & 118 & 35161 & 18919 & 10624 \\
\hline 90 & 0 & 118960 & 122481 & 64440 & 42970 & 30453 \\
\hline 150 & 0 & 73115 & 85056 & 52966 & 40265 & 29684 \\
\hline \multirow{2}{*}{$\begin{array}{c}\text { Temperature/ } \\
{ }^{\circ} \mathrm{C}\end{array}$} & \multirow{2}{*}{$\begin{array}{c}\text { Salinity/ } \\
\text { M }\end{array}$} & \multicolumn{5}{|c|}{ Henry's Constants for Oil Phase/atm } \\
\hline & & $\mathrm{He}$ & $\mathrm{Ne}$ & Ar & $\mathrm{Kr}$ & $\mathrm{Xe}$ \\
\hline 90 & 0 & & & 60 & 25 & 1150 \\
\hline 150 & 0 & 15766 & 15022 & 6162 & 3103 & 2359 \\
\hline
\end{tabular}

\section{Noble Gas Isotope Instrumentation}

The molecular composition can be measured by a gas chromatograph ${ }^{75}$ as well as a quadrupole mass spectrometer $(\mathrm{QMS})^{76}$ or a magnetic deflection mass spectrometer. Although the gas chromatograph and QMS have several advantages over the magnetic deflection mass spectrometer, it cannot analyze the low-concentration isotopes in noble gases $\left(\right.$ e.g. ${ }^{3} \mathrm{He}, \sim 10^{-13} \mathrm{~cm}^{3}$ $\mathrm{STP} / \mathrm{g}$ in groundwater; $\mathrm{Kr}$ isotopes, $\sim 10^{-8} \mathrm{~cm}^{3} \mathrm{STP} / \mathrm{g}$; Xe isotopes, $\left.\sim 10^{-8} \mathrm{~cm}^{3} \mathrm{STP} / \mathrm{g}\right)^{54}$ due to its low mass resolution, low sensitivity and low precision of isotope measurements. ${ }^{77}$ Magnetic deflection mass spectrometers were first introduced

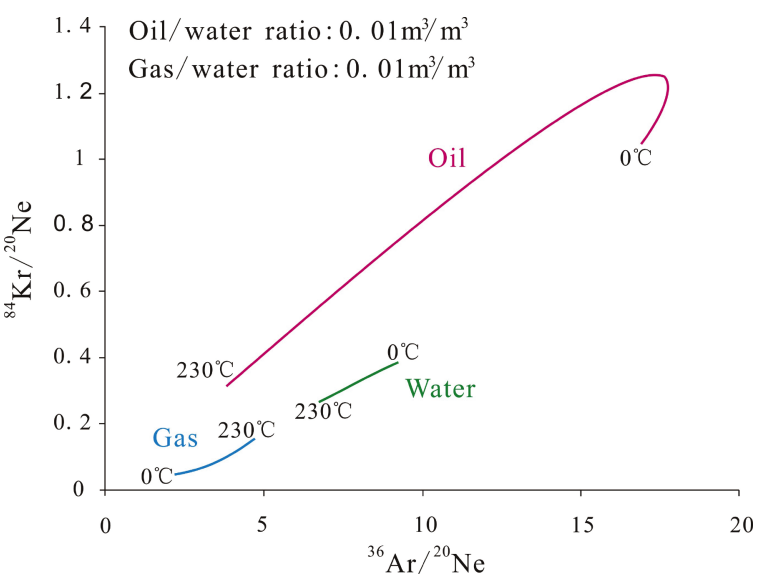

Fig. 4 Evolution of ${ }^{84} \mathrm{Kr} /{ }^{20} \mathrm{Ne}$ and ${ }^{36} \mathrm{Ar} /{ }^{20} \mathrm{Ne}$ ratios for oil, water and gas phases at thermodynamic equilibrium, for temperatures varying from 0 to $230^{\circ} \mathrm{C}$, and gas/water and oil/water. Reprinted from Ref. 69 , Copyright (2013), with permission from Springer Nature.

for the analysis of noble gases in the 1960s. ${ }^{77-80}$ Nowadays, the specific noble gas isotope-ratio mass spectrometer (NG-IRMS) has been used to measure the abundance and isotopic composition of noble gases. A typical noble gas analysis system mainly contains three parts: the pumping system, the purification system and the analytical system (Fig. 5).

NG-IRMS is a static vacuum analysis equipment that can measure extremely trace-amount samples (e.g. $\left.{ }^{3} \mathrm{He}: 10^{-14} \mathrm{ppm}\right)$, 
and in order to achieve this function the whole system needs to be maintained at an ultra-high vacuum (UHV) using an Ion Pump, Turbo Pump, Diffusion Vacuum Pump, and Dry Scroll Vacuum Pumps, etc. The purification line should be stainlesssteel tubes and using all-metal valves, and thus the whole purification system can be heated to $300^{\circ} \mathrm{C}$. The purification devices, Cold Finger (within liquid nitrogen or mixture of dry ice and alcohol), Getter (e.g., SAES ${ }^{\circledR}$ GP50 and NP10) and Titanium Sponge Furnace, should also be installed on the purification line to remove interfering gases (water vapor,

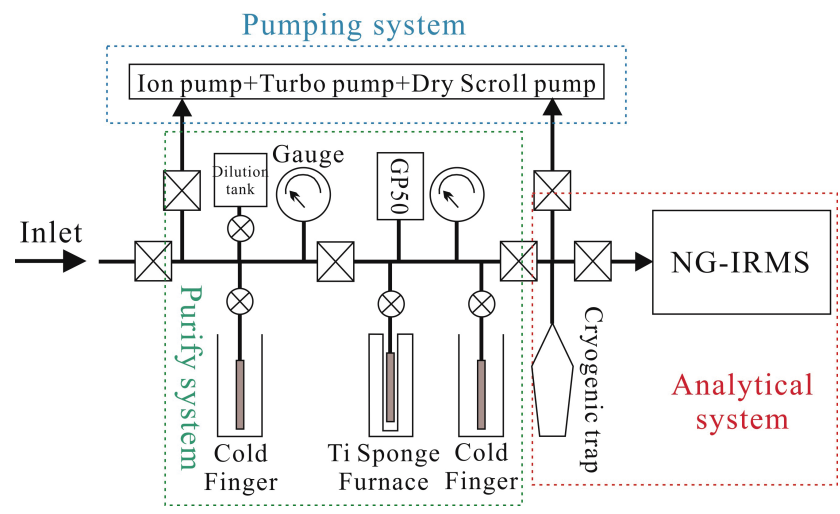

Fig. 5 Schematic diagram of noble gas analysis system.
$\mathrm{C}_{1}-\mathrm{C}_{4}, \mathrm{O}_{2}, \mathrm{~N}_{2}$, and $\mathrm{CO}_{2}$, etc.). Finally, the vacuum in the mass spectrometer section is extremely high $\left(10^{-8}\right.$ to $\left.10^{-10} \mathrm{~Pa}\right)$, and the purification line section can acquire a vacuum of $10^{-7}$ to $10^{-8} \mathrm{~Pa}$. The Cryogenic Trap (Fig. 6) can separate noble gas components ( $\mathrm{He}, \mathrm{Ne}, \mathrm{Ar}, \mathrm{Kr}$, and $\mathrm{Xe}$ ) by lowering the temperature, because when the temperature lower than their respective saturated vapor pressure, different components will condense one by one. Activated charcoal on the cold head of the Cryogenic Trap is to better separate $\mathrm{He}$ and $\mathrm{Ne}$.

\section{Sample Preparation and Analysis Procedures}

\section{4·1 Groundwater samples collection}

Because noble gases are highly volatile, it is important to avoid gas exchange between the water sample and the atmosphere during sampling, transport, and storage. Thus, appropriate containers and collection methods should be selected to obtain groundwater samples. There are three types of sampling vessels for water samples: Giggenbach-type container, traditional copper tube and lead-glass containers (Fig. 7). ${ }^{77,81,82}$ The Giggenbach-type glass container has a potential risk of helium leakage. Copper tubes are not suitable for water samples containing acidic volatiles $\left(\mathrm{HCl}, \mathrm{HF}, \mathrm{H}_{2} \mathrm{~S}\right.$, and/or $\left.\mathrm{SO}_{2}\right)$, which may react severely with copper. Lead-glass containers can conquer the disadvantages of the Giggenbach-type glass container and copper tubes, but it cannot retain the redox conditions of the sulfur species. ${ }^{77}$ In recent studies, both copper

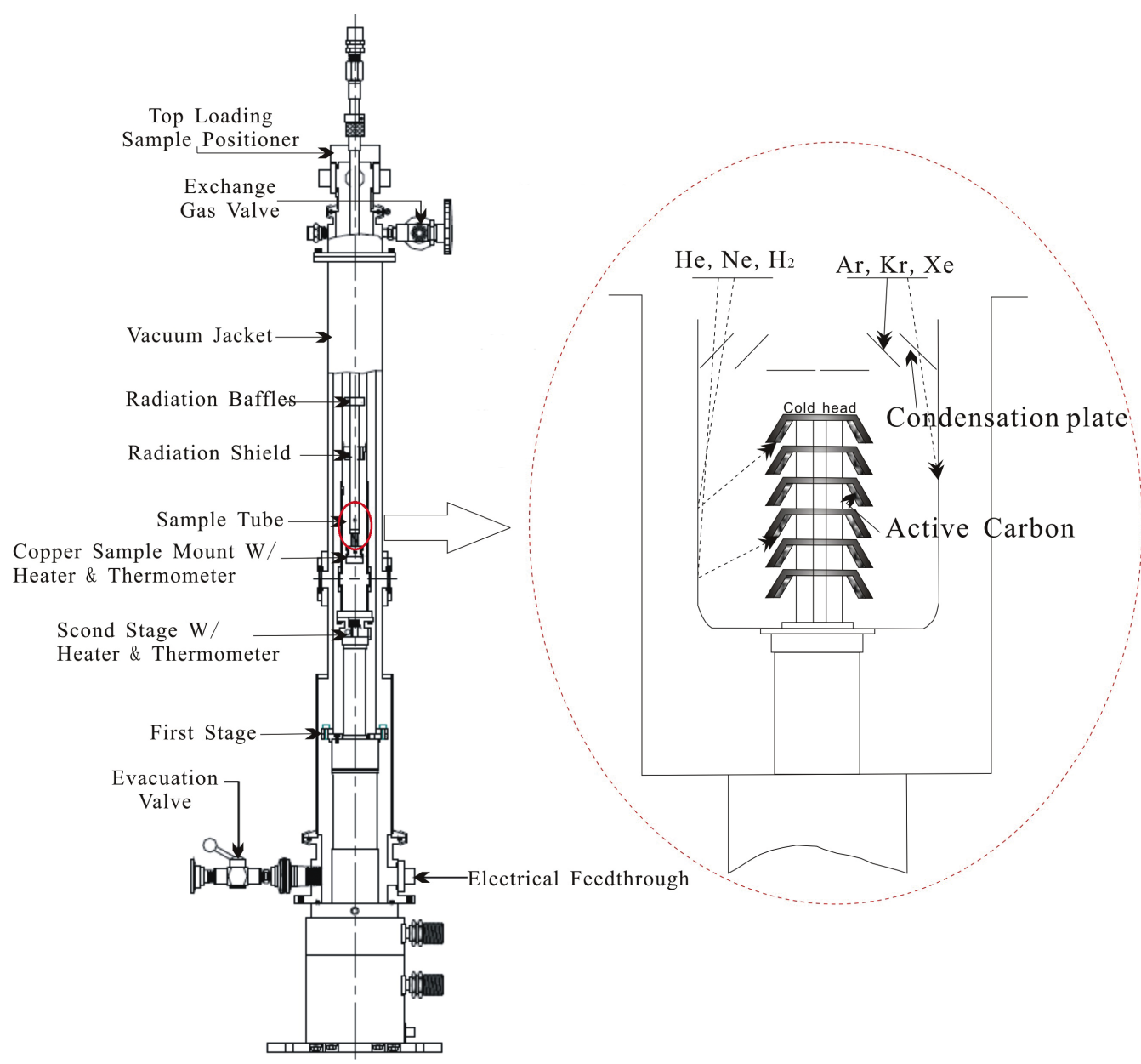

Fig. 6 The schematic diagram of Cryogenic Trap and its cold head. 

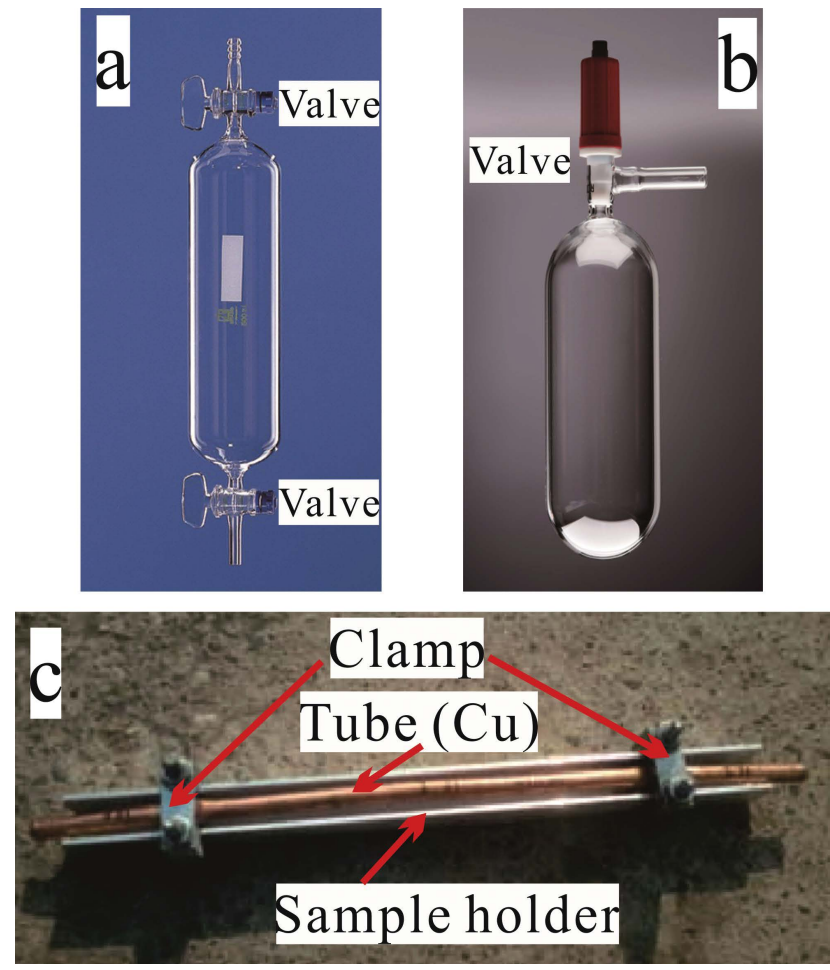

Fig. 7 Actual picture of the sample containers. (a) Lead-glass container with one valve at each end. (b) Giggenbach-type container with only one valve at the top end. (c) Copper tube, mounted on a sample holder (steel clamps on aluminum channels with a sliding connection), there are two clamps at its two ends.

tube and lead-glass containers were used to hold samples, because there were no acidic volatiles in the groundwater, and there was no need to retain the redox conditions. ${ }^{34-36,59,61-63,65,66,70,73}$

Groundwater may contain subsurface-produced gases (e.g. $\mathrm{CO}_{2}, \mathrm{CH}_{4}, \mathrm{He}$ ) whose abundance and isotopic composition are different from those in the atmosphere. ${ }^{81}$ It is essential to avoid contamination from the atmospheric compositions when we collect groundwater samples. To avoid any air bubbles being generated or captured during sampling, and copper tube/leadglass container should be flushed through with groundwater for approximately $10 \mathrm{~min}$. After the groundwater sample is collected into the container, both ends of the container should be sealed underwater using pinch-off clamps, ${ }^{83}$ and groundwater must be transferred into the containers as soon as possible so that it does not have any significant gas loss or gain.

\subsection{Gas extraction and purify}

Dissolved gases must be extracted from groundwater for analyzing the abundance and isotopic composition of noble gases. The ultra-high vacuum (UHV) degassing method is used for degassing dissolved gases in water. In this method, ${ }^{81}$ the copper tube container (filled with $>200 \mathrm{~mL}$ groundwater samples) is directly connected to a stainless extraction vessel (with a specific volume), which will be pumped to UHV by Rotary and Turbo Pumps. When the extraction vessel pressure is reduced to about $10^{-5} \mathrm{~Pa}$, it should be separated from the vacuum pumps by closing the relevant valves. Then, one of the pitch-off clamps that are close to the extraction vessel could be opened, and the sealed part of the copper tube is reopened by a special pair of pliers. ${ }^{84}$ Subsequently, the water is transferred from the copper tube into the extraction vessel, and groundwater begins to degas in the vessel due to the large volume and lower pressure. ${ }^{85,86}$ To enhance the degassing efficiency, an ultrasonic oscillator can be used to produce turbulence in the molecular boundary layer of the water and to enlarge the active surface area of the gas exchange. ${ }^{81}$ If a lead-glass container is used to collect groundwater samples, this extraction equipment can also be employed, and the main extraction processes are the same. ${ }^{86,87}$

The extraction vessel is connected to the purification line. After degassing, the released gases are introduced into the purification line by opening the relevant valves. Aliquots of the samples are expanded into a volume-calibrated container at room temperature. ${ }^{88,89}$ Then, a Cold Figure at dry ice + alcohol temperature is used to remove the water vapor. ${ }^{85}$ After that, samples are expanded to a Ti Sponge Furnace preheated to $900^{\circ} \mathrm{C}$, and then cooled to room temperature over a period of 15 min to remove interfering gases $\left(\mathrm{C}_{1}-\mathrm{C}_{4}, \mathrm{H}_{2} \mathrm{O}, \mathrm{O}_{2}, \mathrm{~N}_{2}\right.$, and $\mathrm{CO}_{2}$, etc.). Subsequently, samples are equilibrated with a $\mathrm{Zr}-\mathrm{Al}$ getter at room temperature, to remove $\mathrm{H}_{2}$. Finally, the purified samples (only $\mathrm{He}, \mathrm{Ne}, \mathrm{Ar}, \mathrm{Kr}$, and $\mathrm{Xe}$ ) are pumped into a Cryogenic Trap at $\sim 10 \mathrm{~K}$. Then, the samples are ready to be released and inlet into NG-IRMS for determination. ${ }^{89-91}$

\subsection{Noble gas measurement procedures}

After the extraction and purification stages, the Cryogenic Trap is heated to $49 \mathrm{~K}$ to release $\mathrm{He}$, and then inlet into the NGIRMS for analysis. Finally, the mass spectrometer and storage volume are evacuated. Subsequently, the temperature of the Cryogenic Trap increased to $84 \mathrm{~K}$ to release $\mathrm{Ne}$ and then expanded into NG-IRMS. When $\mathrm{Ne}$ is measured, a charcoal trap (at $77.3 \mathrm{~K}$ ) mounted on the NG-IRMS is used to remove any residual ${ }^{40} \mathrm{Ar}$ in order to reduce interference on the ${ }^{20} \mathrm{Ne}$ measurements. Then, $\mathrm{Ar}, \mathrm{Kr}$, and $\mathrm{Xe}$ are released one by one from the Cryogenic Trap at 210, 245, and $290 \mathrm{~K}$ and inlet into the NG-IRMS for determination respectively. The releasing temperature of each noble gas $(\mathrm{He}, \mathrm{Ne}, \mathrm{Ar}, \mathrm{Kr}$, or $\mathrm{Xe})$ is not the same in different studies due to the equipment condition. ${ }^{31,59,62-66,89-91} \quad{ }^{4} \mathrm{He},{ }^{20} \mathrm{Ne},{ }^{40} \mathrm{Ar}$ and ${ }^{36} \mathrm{Ar}$ are generally measured on a Faraday cup. Other noble gas isotopes are usually determined on the electron multiplier in the ion counting mode. ${ }^{73,91}$

A calibrated amount of air standard and a procedural blank need to be performed before, during and after the sample analysis exactly in the same manner as the sample measurement. ${ }^{92}$ The mass spectrometer sensitivity and the mass discrimination should be calibrated by comparing to the air standards and blank data. ${ }^{89,92}$ During noble gas isotopes analysis, appropriate mass peaks are monitored to correct for the interferences caused by the doubly charged ions of ${ }^{40} \mathrm{Ar}^{2+}$ and ${ }^{44} \mathrm{CO}_{2}{ }^{2++} \cdot 59,73,89,92$ The measurement errors are $\pm 1 \%$ and $1-5 \%$ for $\mathrm{He}$ and the other noble gases, respectively.

\section{Applications of Noble Gases in Groundwater Contamination}

Oil-water-gas partitioning processes are well recorded in fractionation of the noble gas elemental abundance. Pinti ${ }^{93}$ and Ballentine ${ }^{55}$ found that interactions between groundwater and the hydrocarbons have been on a greater scale than often envisaged in models of hydrocarbon formation and migration, and established the atmosphere-derived and radiogenic noble gases tracer system and the mode of oil-water interactions. Zhou $^{59}$ first used noble gases to construct a physical model that describes the interaction between the groundwater system and the produced gas by the Rayleigh fractionation model of 
groundwater degassing. Darrah ${ }^{34,35}$ provided a new application of noble gas to investigate the fugitive gas contamination of groundwater. In recent years, many researchers around the world have used these theories to discuss the hotspot issues that has impacts on shale gas development concering groundwater quality. ${ }^{31,34-36,61-66,94}$ The specific application cases are described below.

\section{$5 \cdot 1$ Tracing sources of methane}

Thermogenic natural gas is rich in Methane and Radiogenic ${ }^{4} \mathrm{He}$, while ${ }^{20} \mathrm{Ne}$ and ${ }^{36} \mathrm{Ar}$ are mainly from the atmosphere and enter natural gas reservoirs through interactions with formation water. ${ }^{71}$ The ${ }^{4} \mathrm{He} /{ }^{20} \mathrm{Ne}$ and $\mathrm{CH}_{4} /{ }^{36} \mathrm{Ar}$ ratios allow for a direct comparison of the proportion of thermogenic and ASW components, due to similar respective solubility constants of ${ }^{4} \mathrm{He}$ and ${ }^{20} \mathrm{Ne}\left(\beta_{\mathrm{He}} / \beta_{\mathrm{Ne}}=1.2\right.$ at $\left.10^{\circ} \mathrm{C}, \mathrm{STP}\right)$ as well as $\mathrm{CH}_{4}$ and ${ }^{36} \mathrm{Ar}\left(\beta_{\mathrm{CH} 4} / \beta_{\mathrm{Ar}}=1\right.$ at $\left.10^{\circ} \mathrm{C}, \mathrm{STP}\right) .{ }^{34,35,44,60}$

The presence of methane in groundwater would lead to the exsolution of noble gases. This exsolution will be even more severe for the light noble gases $\left(e . g .,{ }^{20} \mathrm{Ne}\right)$ than the heavier ones $\left({ }^{84} \mathrm{Kr}\right.$ and $\left.{ }^{132} \mathrm{Xe}\right)$, because the lighter noble gases will go preferentially into the gas phase. $.55,96$ Normally, the ${ }^{20} \mathrm{Ne}$ excess in groundwater was expected to result from the incorporation of excess air. ${ }^{97}$ But heavy noble gases are less affected by the excess air component than light noble gases. ${ }^{36}$ Wen et al. ${ }^{36}$ collected four groundwater samples with elevated methane concentrations that showed visible fractionation for ${ }^{84} \mathrm{Kr}$ and ${ }^{132} \mathrm{Xe}$ which is caused by a continuous source of natural gas actively migrating into these water wells. However, through comparing the noble gas data of stray gas, Barnett Shale gas and Strawn Group gas they proposed that the source of stray gas in groundwater is likely to be the Strawn Group, not Barnett Shale. This hypothesis was further reinforced by the fact that $\mathrm{F}\left({ }^{132} \mathrm{Xe} /{ }^{36} \mathrm{Ar}\right)$ in water samples is not correlated with the distance to the nearest natural gas well. What is more, there is no correlation between the $\mathrm{CH}_{4} /{ }^{36} \mathrm{Ar}$ ratios and the $\mathrm{Cl}^{-}$concentrations in water, which indicate no anthropogenic deep brine migration.

Crustal noble gases (radiogenic noble gases) ${ }^{4} \mathrm{He}^{*},{ }^{21} \mathrm{Ne}^{*}$, and ${ }^{40} \mathrm{Ar}^{*}$ can also be used to identify the source of methane present in the groundwater. ${ }^{31}$ Eymold et al. ${ }^{62}$ evaluated the groundwater of Karoo Basin with a comprehensive suite of tracers including the noble gas abundance and the isotopic composition, and provide the first comprehensive baseline report of the groundwater characteristics for this region. In his research, the ${ }^{4} \mathrm{He}^{*},{ }^{21} \mathrm{Ne}^{*}$, and ${ }^{40} \mathrm{Ar} *$ correlate to each other and to various hydrocarbon tracers, which suggests a clear presence of thermogenic methane in shallow aquifers of Karoo Basin. Meanwhile, a marked excess in ${ }^{20} \mathrm{Ne}$ and highly elevated ratios of ${ }^{20} \mathrm{Ne} /{ }^{36} \mathrm{Ar}$ without any observable increases in ${ }^{36} \mathrm{Ar}$ also suggested the mixing of an exogenous thermogenic natural gas.

\subsection{Transport mechanisms}

${ }^{4} \mathrm{He} / \mathrm{CH}_{4}$ and ${ }^{20} \mathrm{Ne} /{ }^{36} \mathrm{Ar}$ records important clues about the transport mechanisms by which the hydrocarbon-rich brine reachs the surface, because shallow groundwater mixing with migrated gas could elevate the ${ }^{4} \mathrm{He} / \mathrm{CH}_{4}$ and ${ }^{20} \mathrm{Ne} /{ }^{36} \mathrm{Ar}$ ratios. ${ }^{62,65}$

Darrah et al. ${ }^{34}$ established numerical models to investigate and constrain the subsurface conditions and mechanisms of gas transport to shallow aquifers (Fig. 8). The first model mechanism (gray dash line) supposed that gas and groundwater migrate as a single-phase fluid (no gas-phase, $V_{\text {gas }} / V_{\text {liquid }}=0$ ). In this model, ASW derived noble gas (e.g., ${ }^{20} \mathrm{Ne}$ and $\left.{ }^{36} \mathrm{Ar}\right)$ would not experience any fractionation, ${ }^{57}$ but the groundwater would accumulate radiogenic ${ }^{4} \mathrm{He}$ from the surrounding rocks, causing an increase in the ${ }^{4} \mathrm{He} / \mathrm{CH}_{4}$. In the second and third models

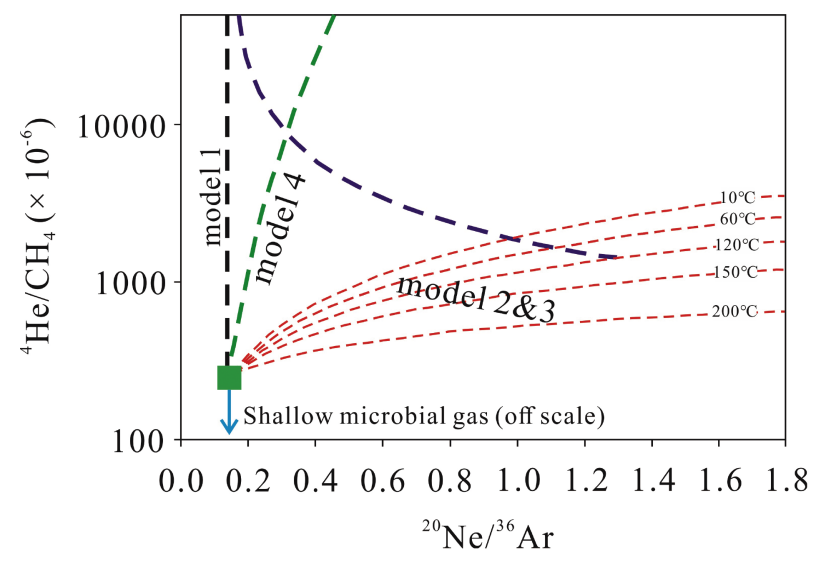

Fig. $8{ }^{4} \mathrm{He} / \mathrm{CH}_{4}$ versus ${ }^{20} \mathrm{Ne} /{ }^{36} \mathrm{Ar}$ in dissolved gas in shallow groundwater samples. Four migration models from a single source of the Marcellus gas: (1) simple 1-phase advection (gray line); (2 and 3) solubility fractionation during the advection of a fluid with a gas phase (i.e., a free-phase gas (2) and a 2-phase fluid (3)), sorted by temperature (red dashed lines); and (4) primary diffusion (green line). Reprinted from Ref. 35, Copyright (2015), with permission from the Elsevier.

(solubility fractionation during the advection of a fluid with a gas phase and a 2-phase fluid), gases would partition according to their respective solubility (Fig. 4, Table 2). The solubility fractionation of noble gases associates with the $V_{\text {gas }} / V_{\text {liquid }}$, geothermal gradient, and the Bunsen solubility constants. ${ }^{98,99}$ In Fig. 8, the red dashed lines indicate the temperature-dependent fractionation of ${ }^{20} \mathrm{Ne} /{ }^{36} \mathrm{Ar}$ and ${ }^{4} \mathrm{He} / \mathrm{CH}_{4}$, and the green line (fourth model) shows the aqueous diffusion of gases and solutes within a static single-phase methane-rich brine. According to the third migration model, Darrah et al. ${ }^{35}$ proposed that Marcellus natural gases migrate from stratigraphic fractures into shallow Upper Devonian aquifers and equilibrate with groundwater. From the elevated ${ }^{4} \mathrm{He} / \mathrm{CH}_{4},{ }^{20} \mathrm{Ne} /{ }^{36} \mathrm{Ar}$, and $\delta^{13} \mathrm{C}_{1}$, they also infer three sequential stages of fluid migration and post-genetic alteration in the northern Appalachian Basin (NAB) ${ }^{35}$

\subsection{Transport pathways}

The concentrations of dissolved ASW (e.g.,${ }^{20} \mathrm{Ne}$ and $\left.{ }^{36} \mathrm{Ar}\right)$ can explain the interactions that occurred between hydrocarbon gas and water. ${ }^{34}$

Significant excesses of ${ }^{20} \mathrm{Ne}$ and correspondingly elevated ratios of ${ }^{20} \mathrm{Ne} /{ }^{36} \mathrm{Ar}$ in $\mathrm{NAB}$ groundwater have confirmed that fault systems may cause the transport of exogenous hydrocarbonrich brines from Devonian source rocks into overlying Upper Devonian aquifer over geologic time, and consequently contaminated the shallow groundwater in NAB. ${ }^{44}$ However, the groundwater samples from Piceance Basin, Colorado, did not show evidence of ${ }^{20} \mathrm{Ne} /{ }^{36} \mathrm{Ar}$ and ${ }^{4} \mathrm{He} / \mathrm{CH}_{4}$ enrichment, the presented that hydrocarbons in shallow aquifers were attributed to substantial free-gas migration or diffusion. ${ }^{65}$ Methane concentrations, isotopic compositions, and noble gases showed that the thermogenic methane was not due to natural mixing of gas-rich formation water with shallow groundwater or natural migration of a free-gas phase, but leaked from an abandoned natural well.

The $\mathrm{CH}_{4}{ }^{36} \mathrm{Ar}$ ratio can also provide information about the depth of groundwater equilibration, due to methane saturation (bubble point) increases with depth, while the abundance of ${ }^{36} \mathrm{Ar}$ is decided by the ASW contributions at recharge. ${ }^{35}$ Darrah 
et al. ${ }^{34}$ supposed seven scenarios (Fig. 1) that could account for the elevated hydrocarbon levels in shallow aquifers overlying the Marcellus and Barnett Shales. Scenarios 1 and 2 show the natural sources of hydrocarbons in groundwater. In scenario 3, the elevated hydrocarbon came from the exsolution of hydrocarbon gas already present in shallow aquifers driven by drilling activities. According to this migration mode, the released hydrocarbon must undergo a phase-separated process that would release hydrocarbon gases from brine without altering the $\mathrm{CH}_{4} /{ }^{36} \mathrm{Ar}$ or ${ }^{4} \mathrm{He} /{ }^{20} \mathrm{Ne}$ in either the migrated gas or the residual fluid because of similar partition coefficients between the respective gases. But scenarios 4 (well annulus), 5 (faulty casing), and 7 (legacy/abandoned wells) would transmit deep thermogenic gases to groundwater with minimal fractionation of hydrocarbon gas, and thus result in high $\mathrm{CH}_{4} /{ }^{36} \mathrm{Ar}$ and ${ }^{4} \mathrm{He} /{ }^{20} \mathrm{Ne}$ ratios. Because Darrah's data had higher $\mathrm{CH}_{4} /{ }^{36} \mathrm{Ar}$ and ${ }^{4} \mathrm{He} /{ }^{20} \mathrm{Ne}$ ratios in migrated gas and residual fluid, they concluded that the fugitive gases in shallow aquifers overlying the Marcellus and Barnett Shales were leaked through annulus cement, production casings, and underground well failure rather than scenarios 3 and 6 .

\subsection{Combined with other geochemical data}

Bernard diagrams $\left(\mathrm{C}_{1} / \mathrm{C}_{2+}\right.$ versus $\left.\delta^{13} \mathrm{C}_{1}\right)$ and Schoell diagrams $\left(\delta \mathrm{D}_{1}\right.$ versus $\left.\delta^{13} \mathrm{C}_{1}\right)$ are often used to identify the origin of methane (Microbial, thermogenic, and/or abiotic) (Fig. 2). ${ }^{52}$ However, due to the role of secondary processes, such as migration and microbial oxidation of hydrocarbons, which can further alter the initial gas isotope values and $C_{1} / C_{2}$ ratio, the content and isotopes of methane are usually an insufficient step toward distinguishing sources of many natural gases (include shale gas). Eymold et al. ${ }^{62}$ investigated methane-rich spring and groundwater samples in Karoo Basin by analyzing the water parameters: dissolved ion chemistry, water isotopes, major gas geochemistry, hydrocarbon gas geochemistry, compoundspecific stable isotopes of hydrocarbons, noble gas elemental and isotope geochemistry. They found a series of correlations between these tracers: helium and neon concentrations correlate positively with methane, ethane, $\mathrm{Cl}$, and $\mathrm{Br}$; the ${ }^{3} \mathrm{He} /{ }^{4} \mathrm{He}$ ratio decreased with both increasing concentrations of ${ }^{4} \mathrm{He}$ and increasing ratios of $\mathrm{He} / \mathrm{Ne}$, and it also displays significant negative correlations to $\delta^{13} \mathrm{C}_{1}, \delta^{13} \mathrm{C}_{2}$, and $\mathrm{C}_{1} / \mathrm{C}_{2+}$; the ${ }^{21} \mathrm{Ne} /{ }^{22} \mathrm{Ne}$ correlates significantly to the proportion of ${ }^{4} \mathrm{He}$, salinity, the concentrations of methane and other hydrocarbon gases and hydrocarbon stable isotopes of hydrogen; and the ${ }^{40} \mathrm{Ar} /{ }^{36} \mathrm{Ar}$ also correlates strongly to the salinity. Through the relations of these different geochemical data, they evaluated the characteristics of methane occurrence, source, and the processes that naturally occur regarding hydrocarbon contamination in shallow aquifers.

\section{Conclusions and Perspectives}

Shale gas production has dramatically increased after hydraulic fracturing and horizontal drilling were applied to shale gas development. However, coming along with the energy boom, the potential for drinking-water contamination in shallow aquifers has aroused significant concerns among the public, politics and scientists, simultaneously. To evaluate the source and potential pathways of the contamination in groundwater has extremely important roles in improving the drink-water quality in the areas of shale gas development. Noble gas compositions preserved in shallow groundwater are not only chemically inert, but also have distinct isotopic and elemental signatures in the mantle, crust, hydrosphere, and atmosphere, as well as unique solubility and diffusion constants during fluid migration. All of these characteristics enhance their utility as geochemical tracers of crustal fluids. Thus, noble gases provide an advantageous supplement for studying the occurrences, sources, and processes concerning methane contamination in shallow aquifers. As discussed in this study, noble gas tracers (e.g., ${ }^{4} \mathrm{He} /{ }^{20} \mathrm{Ne}$, $\mathrm{CH}_{4} /{ }^{36} \mathrm{Ar},{ }^{20} \mathrm{Ne} /{ }^{36} \mathrm{Ar},{ }^{4} \mathrm{He} / \mathrm{CH}_{4},{ }^{84} \mathrm{Kr} /{ }^{36} \mathrm{Ar}$, and ${ }^{132} \mathrm{Xe} /{ }^{36} \mathrm{Ar}$ ) provide increasingly important clues for determining groundwater contaminations.

From recent studies, we can easily find that noble gas tracers have been widely used in the research concerning the occurrence of methane or stray gas in groundwater. ${ }^{44,52,61,62,100}$ Meanwhile, we should focus on variables with less variance in natural samples (e.g., ethane, compound-specific isotopes, noble gases) as opposed to the unilateral application of highly variable methane levels alone. ${ }^{101}$ What is more, the multiple geochemical tracers system, which combining noble gas elemental $(\mathrm{He}, \mathrm{Ne}$, $\mathrm{Ar})$ and isotope geochemistry $\left({ }^{3} \mathrm{He} /{ }^{4} \mathrm{He},{ }^{20} \mathrm{Ne} /{ }^{22} \mathrm{Ne},{ }^{21} \mathrm{Ne} /{ }^{22} \mathrm{Ne}\right.$, ${ }^{20} \mathrm{Ne} /{ }^{36} \mathrm{Ar},{ }^{40} \mathrm{Ar} /{ }^{36} \mathrm{Ar}$ ), major gas geochemistry (e.g., $\mathrm{N}_{2}$ ), hydrocarbon gas geochemistry $\left(\mathrm{C}_{1}-\mathrm{C}_{5}\right)$, compound-specific stable isotopes of hydrocarbons $\left(\delta \mathrm{D}_{1}, \delta^{13} \mathrm{C}_{1}, \delta^{13} \mathrm{C}_{2}\right)$, water isotopes $\left(\delta \mathrm{D}_{\mathrm{H} 2 \mathrm{O}}, \delta^{18} \mathrm{O}_{\mathrm{H} 2 \mathrm{O}}\right)$, water parameters $(\mathrm{pH}, \mathrm{Eh}$, electrical conductivity, temperature), dissolved ion chemistry (e.g., $\mathrm{Na}$, $\mathrm{Ca}, \mathrm{Cl}, \mathrm{Br})$, and tritium $\left({ }^{3} \mathrm{H}\right)$, can provide more powerful tools for studying the sources and migration pathways of methane contamination in shallow aquifers. ${ }^{44,52,62,63,101,102}$ Future work should focus on how to sufficiently combine noble gas data with the conventional geochemical tracers, water parameters and dissolved ion chemistry data. We should establish more and new tracer system models by correct data analysis and employing statistical approach to evaluate the groundwater contamination issue in natural gas development areas. ${ }^{101}$

\section{Acknowledgements}

This research was financially assisted by the National Natural Science Foundation of China (41502143) and the Key Laboratory Project of Gansu Province (1309RTSA041).

\section{References}

1. "Review of Emerging Resources: U.S. Shale Gas and Shale Oil Plays", U.S. Energy Information Administration, Washington, DC 20585, http://www.eia.gov/analysis/ studies/usshalegas/.

2. "World Shale Gas Resources: An Initial Assessment of 14 Regions Outside the United States", U.S. Energy Information Administration, U.S. Department of Energy 2011, https://www.eia.gov/analysis/studies/worldshalegas/ archive/2011/pdf/fullreport.pdf.

3. D. L. Shaffer, L. H. Arias Chavez, M. Ben-Sasson, S. Romero-Vargas Castrillón, N. Y. Yip, and M. Elimelech, Environ. Sci. Technol., 2013, 47, 9569.

4. C. E. Clark, R. M. Horner, and C. B. Harto, Environ. Sci. Technol., 2013, 47, 11829.

5. J. L. Adgate, B. D. Goldstein, and L. M. McKenzie, Environ. Sci. Technol., 2014, 48, 8307.

6. K. B. Gregory, R. D. Vidic, and D. A. Dzombak, Elements, 2011, 7, 181.

7. R. Sugisaki, Nature, 1978, 275, 209.

8. B. G. Rahm and S. J. Riha, Environ. Sci. Policy, 2012, 17, 12.

9. S. F. G. Grasby, A. Brady, C. Sharp, M. McMechan, and 
P. Dunfield, Appl. Geochem., 2016, 68, 10.

10. E. C. Chapman, R. C. Capo, B. W. Stewart, C. S. Kirby, R. W. Hammack, K. T. Schroeder, and H. M. Edenborn, Environ. Sci. Technol., 2012, 46, 3545.

11. R. E. Jackson, A. W. Gorody, B. Mayer, J. W. Roy, M. C. Ryan, and D. R. Van Stempvoort, Groundwater, 2013, 51, 488.

12. S. G. Osborn, A. Vengosh, N. R. Warner, and R. B. Jackson, PNAS, 2011, 108, 8172.

13. C. Rivard, D. Lavoie, R. Lefebvre, S. Séjourné, C. Lamontagne, and M. Duchesne, Int. J. Coal Geol., 2014, 126,64 .

14. N. R. Warner, R. B. Jackson, T. H. Darrah, S. G. Osborn, A. Down, K. G. Zhao, and A. White, PNAS, 2012, 109, 11961.

15. M. Shanafield, P. G. Cook, and C. T. Simmons, Ground Water, 2018, 57, 547.

16. N. E. Lauer, J. S. Harkness, and A. Vengosh, Environ. Sci. Technol., 2016, 50, 5389.

17. L. A. Richards, D. Magnone, B. E. V. Dongen, C. J. Ballentine, and D. A. Polya, Appl. Geochem., 2016, 63, 190.

18. "Hydraulic Fracturing", US Environmental Protection Agency, Washington, DC, http://water.epa.gov/type/ groundwater/uic/class2/hydraulicfracturing/.

19. D. M. Kargbo, R. G. Wilhelm, and D. J. Campbell, Environ. Sci. Technol., 2010, 44, 5679.

20. D. Kay, "The Economic Impact of Marcellus Shale Gas Drilling What have We Learned? What are the Limitations? Working Paper Series: A Comprehensive Economic Analysis of Natural Gas Extraction in the Marcellus Shale", 2011, Cornell University, Ithaca, NY.

21. "Study of the Potential Impacts of Hydraulic Fracturing on Drinking Water Resources: Progress Report Environmental Protection Agency", Washington, DC, https://www.epa. gov/hfstudy/study-potential-impacts-hydraulic-fracturingdrinking-water-resources-progress-report-0.

22. E. Brown, K. Hartman, C. P. Borick, B. G. Rabe, and T. M. Ivacko, "The National Surveys on Energy and Environment Public Opinion on Fracking: Perspectives from Michigan and Pennsylvania”, 2013, Social Science Electronic Publishing, https://ssrn.com/abstract $=2313276$.

23. E. L. Hill, Journal of Health Economics, 2018, 61, 134.

24. E. Hill, and L. Ma, American Economic Review, 2017, 107, 522.

25. C. H. Yu, S. K. Huang, P. Qin, and X. L. Chen, Energy Policy, 2018, 113, 123.

26. A. L. Israel, G. Wong-Parodi, T. Webler, and P. C. Stern, Energy Res. Social Sci., 2015, 8, 139.

27. S. M. Olmstead, L. A. Muehlenbachs, J.-S. Shih, Z. Y. Chu, and A. J. Krupnick, PNAS, 2013, 110, 4962.

28. "Hydraulic Fracturing for Oil and Gas: Impacts from the Hydraulic Fracturing Water Cycle on Drinking Water Resources in the United States (Final Report)", https:// www.epa.gov/hfstudy.

29. N. R. Warner, C. A. Christie, R. B. Jackson, and A. Vengosh, Environ. Sci. Technol., 2013, 47, 11849.

30. R. D. Vidic, S. L. Brantley, J. M. Vandenbossche, D. Yoxtheimer, and J. D. Abad, Science, 2013, 340, 826.

31. T. Wen, M. C. Castro, J.-P. Nicot, C. M. Hall, D. L. Pinti, P. Mickler, R. Darvari, and T. Larson, Environ. Sci. Technol., 2017, 51, 6533.

32. A. I. Gresov, A. V. Yatsuk, A. I. Obzhirov, and E. P. Razvozzhaeva, Russian Journal of Pacific Geology, 2018, $12,225$.

33. R. B. Jackson, A. Vengosh, T. H. Darrah, N. R. Warner, A.
Down, R. J. Poreda, S. G. Osborn, K. G. Zhao, and J. D. Karr, PNAS, 2013, 110, 11250.

34. T. H. Darrah, A. Vengosh, R. B. Jackson, N. R. Warner, and R. J. Poreda, PNAS, 2014, 111, 14076.

35. T. H. Darrah, R. B. Jackson, A. Vengosh, N. R. Warner, C. J. Whyte, T. B.Walsh, A. J. Kondash, and R. J. Poreda, Geochim. Cosmochim. Acta, 2015, 170, 321.

36. T. Wen, M. C. Castro, J.-P. Nicot, C. M. Hall, T. Larson, P. Mickler, and R. Darvari, Environ. Sci. Technol., 2016, 50, 12012.

37. H. Li and K. H. Carlson, Environ. Sci. Technol., 2014, 48, 1484.

38. N. R. Warner, T. M. Kresse, P. D. Hays, A. Down, J. D. Karr, R. B. Jackson, and A. Vengosh, Appl. Geochem., 2013, 35, 207.

39. A. M. Martini, J. M. Budai, L. M. Walter, and M. Schoell, Nature, 1996, 383, 155.

40. D. A. Stolper, A. M. Martini, M. Clog, P. M. Douglas, S. S. Shusta, D. L. Valentine, A. L. Sessions, and J. M. Eiler, Geochim. Cosmochim. Acta, 2015, 161, 219.

41. E. G. Elliott, A. S. Ettinger, B. P. Leaderer, M. B. Bracken, and N. C. Deziel, J. Exposure Sci. Environ. Epidemiol., 2017, 27, 90

42. "Assessment of the Potential Impacts of Hydraulic Fracturing for Oil and Gas on Drinking Water Resources (External Review Draft)", U.S. Environmental Protection Agency, Washington, DC, EPA/600/R-15/047, http://cfpub. epa.gov/ncea/hfstudy/recordisplay.cfm?deid=244651.

43. V. F. Bense, T. Gleeson, S. E. Loveless, O. Bour, and J. Scibek, Earth Sci. Rev., 2013, 127, 171.

44. T. H. Darrah, R. B. Jackson, A. Vengosh, N. R. Warner, and R. J. Poreda, Ground Water, 2015, 53, 23.

45. A. Andrews, P. Folger, M. Humphries, C. Copeland, M. Tiemann, R. Meltz, and C. Brougher, "Unconventional Gas Shales: Development, Technology, and Policy Issues", Congressional Research Service Reports, 2010, Library of Congress, Congressional Research Service.

46. S. L. Brantley, D. Yoxtheimer, S. Arjmand, P. Grieve, R. Vidic, J. Pollak, G. T. Llewellyn, J. Abad, and C. Simon, Int. J. Coal Geol., 2014, 126, 140.

47. G. T. Llewellyn, F. Dorman, J. L. Westland, D. Yoxtheimer, P. Grieve, T. Sowers, E. Humston-Fulmer, and S. L. Brantley, PNAS, 2015, 112, 6325.

48. L. J. Molofsky, J. A. Connor, A. S. Wylie, T. Wagner, and S. K. Farhat, Ground Water, 2013, 51, 333.

49. E. C. Botner, A. Townsend-Small, D. B. Nash, X. Xu, A. Schimmeimann, and J. H. Miller, Environ. Monit. Assess. 2018, 322.

50. E. Barth-Naftilan, J. Sohng, and J. E. Saiers, PNAS, 2018, 115, 6970.

51. B. J. Tilley and K. Muehlenbachs, "Fingerprinting of Gas Contaminating Groundwater and Soil in a Petroliferous Region", Proceedings of the 2011 INEFF Conference, 2012, Alberta, Canada, Environmental Forsenics, Royal Society of Chemistry, London, 115.

52. J. C. McIntos, M. J. Hendry, C. Ballentine, R. S. Haszeldine, B. Mayer, G. Etiope, M. Elsner, T. H. Darrah, A. Prinzhofer, S. Osborn, L. Stalker, O. Kuloyo, Z.-T. Lu, A. Martini, and B. Sherwood Lollar, Environ. Sci. Technol., 2019, 53, 1063.

53. T. Wen, M. C. Castro, B. R. Ellis, C. M. Hall, and K. C. Lohmann, Chem. Geol., 2015, 417, 356.

54. M. Ozima and F. A. Podosek, "Noble Gas Geochemistry", 2nd ed., 2002, Cambridge University Press, Cambridge.

55. C. J. Ballentine, R. K. O'nions, E. R. Oxburgh, F. Horvath, and J. Deak, Earth Planet. Sci. Lett., 1991, 105, 229. 
56. R. K. Onions and C. J. Ballentine, Philos. Trans. R. Soc. London, Ser, 1993, A344, 141.

57. C. J. Ballentine, R. Burgess, and B. Marty, Rev. Mineral. Geochem., 2002, 47, 539.

58. Z. Zhou, C. J. Ballentine, R Kipfer, M. Schoell, and S. Thibodeaux, "A Noble Gas Tool to Quantify the Interaction of Groundwater with Coalbed Methane, San Juan Basin, USA", 2003, Vol. 17, EGS-AGU-EUG Joint Assembly, $608-615$.

59. Z. Zhou, C. J. Ballentine, R. Kipfer, M. Schoell, and S. Thibodeaux, Geochim. Cosmochim. Acta, 2005, 69, 5413.

60. D. J. Byrne, P. H. Barry, M. Lawson, and C. J. Ballentine, Geological Society, London, Special Publications, 2017, $468,127$.

61. T. Wen, X. Z. Niu, M. Gonzales, G. J. Zheng, Z. H. Li, and S. L. Brantley, Environ. Sci. Technol., 2018, 52, 7149.

62. W. K. Eymold, K. Swana, M. T. Moore, C. J. Whyte, J. S. Harkness, S. Talma, R. Murray, J. B. Moortgat, J. Miller, A. Vengosh, and T. H. Darrah, Ground Water, 2018, 56, 204.

63. J. S. Harkness, T. H. Darrah, N. R. Warner, C. J. Whyte, M. T. Moore, R. Millot, W. Kloppmann, R. B. Jackson, and A. Vengosh, Geochim. Cosmochim. Acta, 2017, 208, 302.

64. T. M. Huang, Z. H. Pang, J. Tian, Y. M. Li, S. Yang, and L. Luo, J. Radioanal. Nucl. Chem., 2017, 312, 577.

65. P. B. McMahon, J. C. Thomas, J. T. Crawford, M. M. Dornblaser, and A. G. Hunt, Sci. Total Environ., 2018, 634, 791.

66. P. H. Barry, J. T. Kulongoski, M. K. Landon, R. L. Tyne, J. M. Gillespie, M. J. Stephens, D. J. Hillegonds, D. J. Byrne, and C. J. Ballentine, Earth Planet. Sci. Lett., 2018, 496, 57.

67. D. R. Hilton and D. Porcelli, "Noble Gases as Mantle Tracers", 2014, Treatise on Geochemistry, Amsterdam, Boston, Elsevier/Pergamon.

68. D. Porcelli, C. J. Ballentine, and R. Wieler, Rev. Mineral. Geochem., 2002, 47, 1.

69. A. Prinzhofer, "Noble Gas in Oil and Gas Accumulations", in "The Noble Gases as Geochemical Tracers. Advances in Isotope Geochemistry", ed. P. Burnard, 2013, Springer, Berlin, Heidelberg.

70. C. J. Ballentine and B. S. Lollar, Geochim. Cosmochim. Acta, 2002, 66, 2483.

71. S. M. V. Gilfillan, B. Sherwood Lollar, G. Holland, D. Blagburn, S. Stevens, M. Schoell, M. Cassidy, Z. J. Ding, Z. Zhou, G. Lacrampe-Couloume, and C. J. Ballentine, Nature, 2009, 458, 614.

72. W. Aeschbach-Hertig, H. El-Gamal, M. Wieser, and L. Palcsu, Water Resour. Res., 2008, 44, 853.

73. Z. Zhou, C. J. Ballentine, M. Schoell, and S. H. Stevens, Geochim. Cosmochim. Acta, 2012, 86, 257.

74. L. Ma, M. C. Castro, and C. M. Hall, Geochem. Geophys. Geosys., 2009, 10, 1.

75. A. Vengosh, R. B. Jackson, N. Warner, T. H. Darrah, and A. Kondash, Environ. Sci. Technol., 2014, 48, 8334.

76. Y. Sano, T. Tominaga, and H. Wakita, Geochem. J., 1982, 16, 279.

77. Y. Sano and T. P. Fischer, "The Analysis and Interpretation of Noble Gases in Modern Hydrothermal Systems", in "The Noble Gases as Geochemical Tracers. Advances in Isotope Geochemistry", ed. P. Burnard, 2013, Springer, Berlin, Heidelberg.
78. R. A. Canalas, E. C. Alexander, and O. K. Manuel, J. Geophys. Res., 1968, 73, 3331.

79. E. Mazor, G. J. Wasserburg, and H. Craig, Deep-Sea Research and Oceanographic Abstracts, 1964, 11, 929.

80. E. Mazor and G. J. Wasserburg, Geochim. Cosmochim. Acta, 1965, 29, 443.

81. U. Beyerle, W. Aeschbach-Hertig, D. M. Imboden, H. Baur, T. Graf, and R. Kipfer, Environ. Sci. Technol., 2000, 34, 2042.

82. R. F. Weiss, Deep-Sea Research and Oceanographic Abstracts, 1968, 15, 695.

83. G. Winckler, R. Kipfer, W. Aeschbach-Hertig, R. Botz, M. Schmidt, S. Schuler, and R. Bayer, Geochim. Cosmochim. Acta, 2000, 64, 1567.

84. R. Kipfer, "Primordiale Edelgase als Tracer für Fluide aus dem Erdmantel”, PhD Thesis, ETH Zürich, 1991.

85. Y. Sano and H. Wakita, Chem. Geol. Isotope Geosci., 1987, 66, 217.

86. Y. Sano, N. Takahata, T. Kagoshima, T. Shibata, T. Onoue, and D. Zhao, Sci. Rep., 2016, 6, 37939.

87. Y. Sano, T. Hara, N. Takahata, S. Kawagucci, M. Honda, Y. Nishio, W. Tanikawa, A. Hasegawa, and K. Hattori, Nat. Commun., 2014, 5, 3084.

88. C. J. Ballentine, B. Marty, B. S. Lollar, and M. Cassidy, Nature, 2005, 433, 33.

89. S. M. V. Gilfillan, C. J. Ballentine, G. Holland, D. Blagburn, B. Sherwood Lollar, S. Stevens, M. Schoell, and M. Cassidy, Geochim. Cosmochim. Acta, 2008, 72, 1174.

90. T. H. Darrah, D. Tedesco, F. Tassi, O. Vaselli, E. Cuoco, and R. J. Poreda, Chem. Geol., 2013, 339, 16.

91. C. H. Cao, M. J. Zhang, Q. Y. Tang, Y. Yang, Z. G. Lv, T. W. Zhang, C. Chen, H. Yang, and L. W. Li, Mar. Pet. Geol., 2018, $89,38$.

92. M. C. Castro, L. Ma, and C. M. Hall, Earth Planet. Sci. Lett., 2009, 279, 174.

93. D. L. Pinti and B. Marty, Geochim. Cosmochim. Acta, 1995, 59, 3389.

94. R. L. Kreuzer, T. H. Darrah, B. S. Grove, M. T. Moore, N. R. Warner, W. K. Eymold, C. J. Whyte, G. Mitra, R. B. Jackson, A. Vengosh, and R. J. Poreda, Ground Water, 2018, 56, 225.

95. A. Bosch and E. Mazor, Earth Planet. Sci. Lett., 1988, 87, 338.

96. R. E. Zartman, G. J. Wasserburg, and J. H. Reynolds, J. Geophys. Res., 1961, 66, 277.

97. T. H. E. Heaton and J. C. Vogel, J. Hydrol., 1981, 50, 201.

98. R. F. Weiss, Deep Sea Research and Oceanographic Abstracts, 1971, 18, 225.

99. R. F. Weiss, Journal of Chemical Engineering Data, 1971, $16,1976$.

100. A. S. Kornacki and M. McCaffrey, "Monitoring the Active Migration and Biodegradation of Natural Gas in the Trinity Group Aquifer at the Silverado Development in Southern Parker County, Texas. 2014", AAPG Annual Convention and Exhibition, April 7, 2014.

101. T. H. Darrah, Ground Water, 2018, 56, 1.

102. M. T. Moore, D. S. Vinson, C. J. Whyte, W. K. Eymold, T. B. Walsh, and T. H. Darrah, Geological Society, London, Special Publications, 2018, 468, 151. 